\title{
Suitability of donata and BRS F 132 cultivar for the potato processing industry
}

\author{
Ariana Mota PEREIRA ${ }^{1 *}$ (D), Mateus de Paula GOMES ${ }^{2}$, Maria Eduarda da Silva GUIMARÃES 3 , \\ Renata Ranielly Pedroza CRUZ ${ }^{1}$, Antonia Gorete da Silva GALDINO ${ }^{1}$, Ana Izabella FREIRE ${ }^{1}$, \\ Wellington Souto RIBEIRO ${ }^{1}$, Fernando Luiz FINGER ${ }^{1}$
}

\begin{abstract}
Changes in the population's eating habits have expanded the French fries market. However, the need for refrigerated storage to supply sprouts and maintain a constant supply to the industry has led to a reduced number of cultivars suitable for processing due to the accumulation of sugars and browning after frying. Because of this, the objective of this study was to evaluate the suitability of the Donata and BRS F132 cultivars for use in the pre-fried potato processing industry. The tubers were stored at 6 and $8{ }^{\circ} \mathrm{C}$ for up to 180 days and the analysis of sprouting, total soluble sugar (TSS), reducing sugar (RS), non-reducing sugar (NRS), post-frying color by scale visual color used by the industry and $\mathrm{L}^{*}$ and $\mathrm{b}^{*}$ parameters. The sprouting was higher at $8^{\circ} \mathrm{C}$ and in the BRS F 132 cultivar. The sugar content was high in both cultivars, however, the color remained adequate. It is concluded that the Donata and BRS F132 cultivars are suitable for the potato processing industry, and Donata presented better quality parameters. Conditioning at $8{ }^{\circ} \mathrm{C}$ is recommended in both cultivars that maintained the quality for 180 days.
\end{abstract}

Keywords: sugars; Maillard reaction; sprouting; French fries.

Practical Application: This study is important for the potato processing industry due to the low availability of suitable genotypes for the industry, evaluating the potential use of cultivars Donata and BRS F 131, which presented good quality parameters, with adequate color and reduced sprouting. Being suitable for industrial use, they can be stored for up to 180 days at $8{ }^{\circ} \mathrm{C}$. Long period of time that would allow the constant supply of the product to the industry.

\section{Introduction}

The industrialization of potato production has increased due to the increase in the number of fast foods, restaurants and the need for more convenience, causing greater consumption of processed foods, with emphasis on the consumption of French fries (Faulkner, 2015).

Currently, $40-50 \%$ of American and $75 \%$ of Dutch potato production are destined for processing (National Agricultural Statistics Service, 2013; Wustman et al., 2011). However, in developing countries, such as Brazil, most of the production is still destined for the fresh market, despite the change in the consumer trend. This scenario is due to the lack of infrastructure and adequate technology, such as the use of cultivars that meet the requirements of the industries.

The use of cultivars with a greater aptitude for processing reduces costs and causes the formation of higher quality products, and this has been one of the main factors that have led to the import of processed products (Garcia et al., 2015).

Among the requirements that the cultivars must present to the industry, the most important in fries is the color after frying (Araújo et al., 2016), which is influenced by the conditions of storage and frying (Bastos et al., 2011).
When the tubers are stored at temperatures below 8 and $10^{\circ} \mathrm{C}$, for the constant supply of tubers to industry and for suppression of sprouting, the Maillard reaction can occur, which consists of the condensation of the reducing sugar carbonyl group with the amino group free of amino acids, peptides or proteins, with the formation of the Schiff base which undergoes rearrangements, producing the Amadori product (aldose sugar) or Heyns product (ketosis sugar) which are fragmented leading to reactions of dehydration, enolization and retroaldolization, forming various products that when polymerized together with lysine or arginine residues in proteins, resulting in the formation of dark pigments known as melanoidins (Bastos et al., 2011; Brião et al., 2011; Liu et al., 2014). These pigments promote the browning of the sticks after frying, making them unsuitable for the industry.

In addition to the visual factor of the sticks, Maillard reaction is related to the formation of acrylamide (Di Stefano \& Avellone, 2014), a carcinogen, which has been verified in high concentrations in French fries (Pedreschi et al., 2014; McCombie et al., 2016; Esposito et al., 2017).

The concentration of sugars in the tubers has been considered the main factor to reduce acrylamide formation and browning (Paul et al., 2016; Elmore et al., 2015). However, there is a 
wide range of sugar concentrations among potato genotypes (Halford et al., 2012), making them not all suitable for processing after cold storage, which promotes the accumulation of these sugars in response to the condition of stress.

Because of this, the objective of this study was to evaluate the suitability of the Donata and BRS F132 cultivars for use in the pre-fried potato processing industry.

\section{Materials and method}

Tubers of Donata (37824) and BRS F132 (41671) cultivars were obtained from the commercial production area of Perdizes,

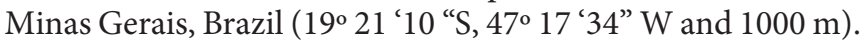
The tubers were manually harvested and cured in the field, then they were transported to the Post-harvest Physiology Laboratory of the Phytotechnics Department of the Viçosa Federal University, where they were stored at $6(\mathrm{UR} 90 \% \pm 2)$ and $8{ }^{\circ} \mathrm{C}(\mathrm{UR} 90 \% \pm 2)$ in the absence of light for up to 180 days.

Sprouting and TSS (total soluble sugars), RS (reducing sugars) and NRS (non-reducing sugars) were determined at 60, 120 and 180 days in tubers at 6 and $8^{\circ} \mathrm{C}$. The visual coloration based on the color scale used by the industry and the parameters $\mathrm{L}^{*}$ and $\mathrm{b}^{*}$ were evaluated at $0,60,120$ and 180 days only on tubers at $8^{\circ} \mathrm{C}$.

For the determination of TSS and RS, $5 \mathrm{~g}$ of fresh mass was removed from the tubers to which $80 \%$ ethanol was added at $100{ }^{\circ} \mathrm{C}$. The mixture was ground and centrifuged three times for $10 \mathrm{~min}$ at $1500 \mathrm{~g}$. At each centrifugation, the samples were filtered and the combined final volume of the filtrations was standardized and used for the quantification of TSS and RS (Dubois et al., 1956).

The TSS were quantified by the Phenol-sulfuric method (Dubois et al., 1956), using 1\% sucrose to make the standard curve. The reaction was composed of $250 \mu \mathrm{L}$ of the extract, $250 \mu \mathrm{L}$ of $5 \%$ phenol and $1.25 \mathrm{~mL}$ of sulfuric acid. Subsequently, the reaction was placed in a thermostatic bath for $20 \mathrm{~min}$ at $30^{\circ} \mathrm{C}$. The reading performed on a spectrophotometer (Genesys-10UV, sacannig) at $490 \eta \mathrm{m}$ and expressed in \%.

The RS were determined using the dinitrosalicylic acid (DNS) methodology described by Gonçalves et al. (2010) with adaptations $0.2 \%$ fructose was used to make the curve. For the preparation of $500 \mathrm{~mL}$ of DNS, $5 \mathrm{~g}$ dinitrosalicylic acid dissolved in $250 \mathrm{~mL}$ of distilled water at $80^{\circ} \mathrm{C}, 100 \mathrm{~mL}$ of $2 \mathrm{~N}$ $\mathrm{NaOH}$ and $150 \mathrm{~g}$ of sodium and potassium tartrate were used. The reaction consisted of $500 \mu \mathrm{L}$ of DNS and $500 \mu \mathrm{L}$ of the sample, subsequently placed in water at $100^{\circ} \mathrm{C}$ and after $5 \mathrm{~min}$ added $4 \mathrm{~mL}$ of distilled water. The readings were performed on a spectrophotometer (Genesys-10UV, sacannig) at $540 \mathrm{~nm}$ and expressed as a percentage.

The NRS were calculated by the difference between SST and RS and expressed as a percentage.

To evaluate the post-frying color, the tubers were cut into chopsticks, with a manual cutter and fried in an electric fryer, with a capacity of $3 \mathrm{~L}$ (Model: Ford ${ }^{\circ}$ ). Frying was carried out for 4 min at $180^{\circ} \mathrm{C}$, following the recommendations of the industries and according to previous studies in which they determine a reduction in the accumulation of acrylamide in this temperature and time range (Romani et al., 2008).

The color of post-fry potatoes was determined visually based on the scale of notes recommended by the 'United States Standards for Grades of Frozen French Fried Potatoes' (United States Department of Agriculture, 1967) and by the potato processing industry in grades ranging from 1 to 5 . And by the use of the Color Reader CR-10 colorimeter, Minolta, which has the components $\mathrm{L}^{*}, \mathrm{a}^{*}, \mathrm{~b}^{*}, \mathrm{c}^{*}$ (chroma) and the angle Hue, and for potato tubers the parameter $L^{\star}$ was used which refers to the degree of brightness of the sample, varying from light (values close to 100) to dark (values close to 0 ) and the component $\mathrm{b}^{*}$ varies from blue (negative values) to yellow (positive values) (Minolta Corp., 1994).

The experiment was carried out in a completely randomized design, in a split-plot scheme with five replications, each replication consisting of two tubers. For the parameters $\mathrm{L}^{\star}$ and $\mathrm{b}^{\star}$ the plots were the cultivars (Donata and BRS F132) and the subplots the storage times $(60,120$ and 180 days). While for SST, RR and NRS the subdivided plot was made, the plot being the cultivars (Donata and BRS F132), the subplot the temperatures (6 and $\left.8{ }^{\circ} \mathrm{C}\right)$ and the subplot the storage time $(60,120,180)$. The data were subjected to analysis of variance and regression using the System of Statistical Analysis and Genetics used at the Viçosa Federal University (Cruz, 2006).

\section{Results and discussions}

Regardless of temperature and cultivar, at 60 days of storage, there was no sprouting (Figure 1). At 120 and 180 days, sprouting was greater in tubers at $8{ }^{\circ} \mathrm{C}$ compared to $6^{\circ} \mathrm{C}$ and the sprout of BRS F132 cultivar was larger than that of 'Donata' (Figure 1).

The reduction of $2{ }^{\circ} \mathrm{C}$ in the storage temperature was not enough to delay the start of sprouting, which started at 120 days. However, it promoted a reduction in the size of the sprouts. Thus, storage at $8{ }^{\circ} \mathrm{C}$ is more suitable due to the energy costs of the refrigeration chamber.

TSS and RS showed no difference in relation to cultivars, indicating that $\mathrm{CV}$. Donata and BRS F132 have similar levels of these sugars (Figure 2). However, the NRS showed higher content in the cultivar BRS F 132 (0.47\%) compared to Donata (0.24\%).

The levels of TSS, RS and NRS were $0.77 ; 0.33$ and $0.52 \%$ at $6{ }^{\circ} \mathrm{C}$ and $0.28,0.11$ and $0.18 \%$ at $8{ }^{\circ} \mathrm{C}$, respectively. The highest sugar content at $6^{\circ} \mathrm{C}$ occurs due to the activation of carbohydrate metabolism enzymes, the lower the temperature, the greater the transcription of these enzymes. Among the TSS concentration, the largest proportions are found in the form of NRS, indicating that its conversion into RS was still occurring at both temperatures.

When potato tubers are exposed to low temperatures, there is a reduction in the starch pool, due to inhibition of their synthesis enzymes, such as AGPase and GBSS and increased transcription of b-amylase genes, promoting starch degradation in sucrose (NRS) which is broken down into glucose and fructose (RS) by the vacuolar acid invertase in potato tubers (WiberleyBradford et al., 2014). 


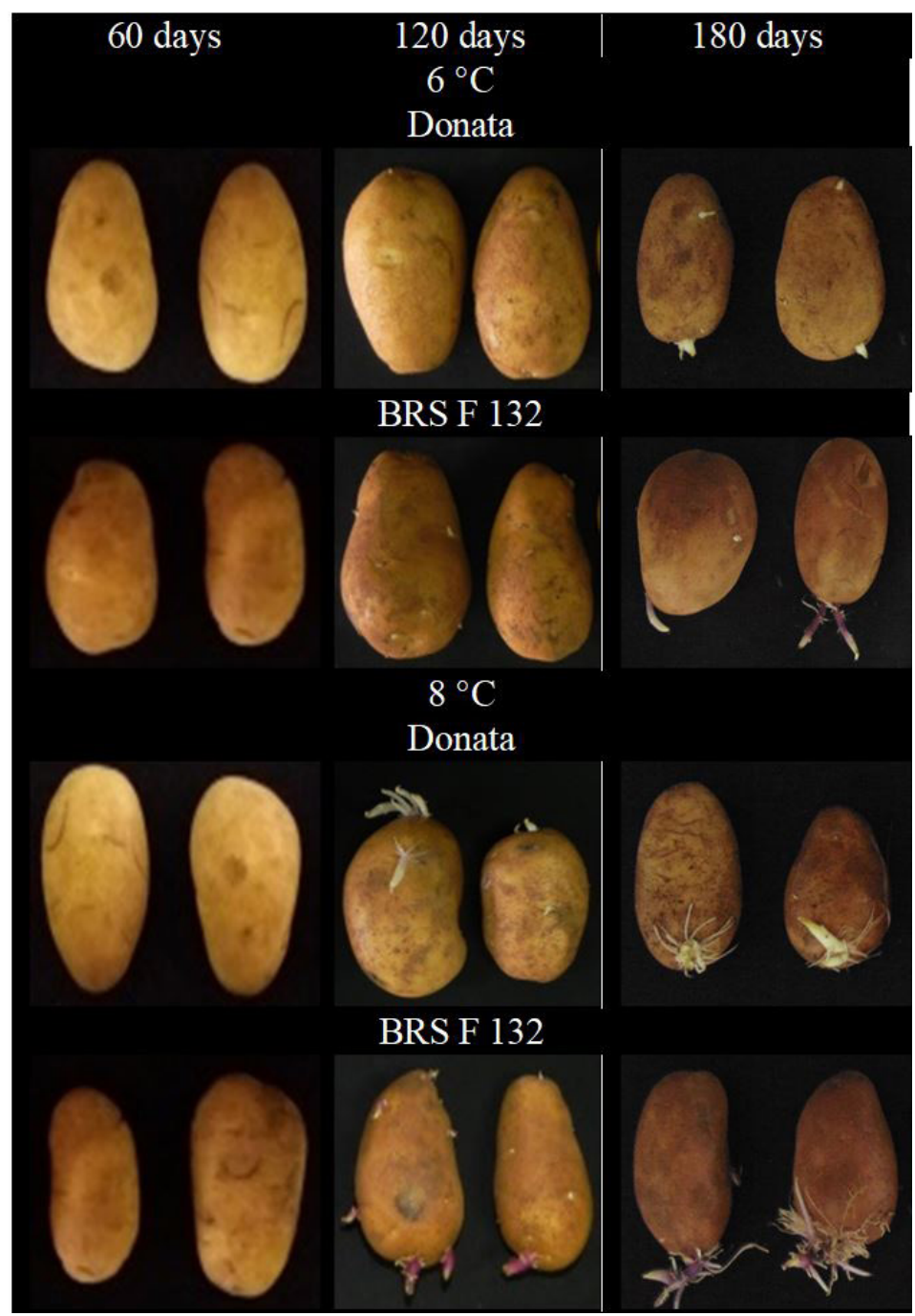

Figure 1. Sprouting of Donata and BRS F 132 cultivars tubers stored at 6 and $8^{\circ} \mathrm{C}$ for 60,120 and 180 days.

The time of exposure to low temperatures increased the concentration of SST and RS (Figure 2). TSS values increased from 0.37 to $0.70 \%$ and RS values increased from 0.08 to $0.38 \%$ from 60 to 180 days (Figure 2). The increase in RS occurs due to the increase in enzyme activity of invertase, as observed Amjad et al., 2020, in which the activity of the enzyme increases with the reduction of temperature, the lower the temperature the greater the enzymatic stimulus, the activity being enzyme and the accumulation of RS varies with the cultivar.

The sugar content was high, being above the indicated for the processing in the form of the sticks that is between 0.20 and $0.25 \%$ (Zorzella et al., 2003). However, when evaluating the visual coloration based on the color scale used by the industry in the tubers of both cultivars at $8{ }^{\circ} \mathrm{C}$, which was the temperature that promoted less sugar accumulation. The sticks were classified in category 2 for the Donata cultivar during the entire storage (Figure 3 ) and for the BRS F 132 cultivar in category 2 at 0 and 60 days, and in category 3 at 120 and 180 days (Figure 3 ).

The high correlation between the sugar content and the color of the sticks after frying (Araújo et al., 2016; Duarte-

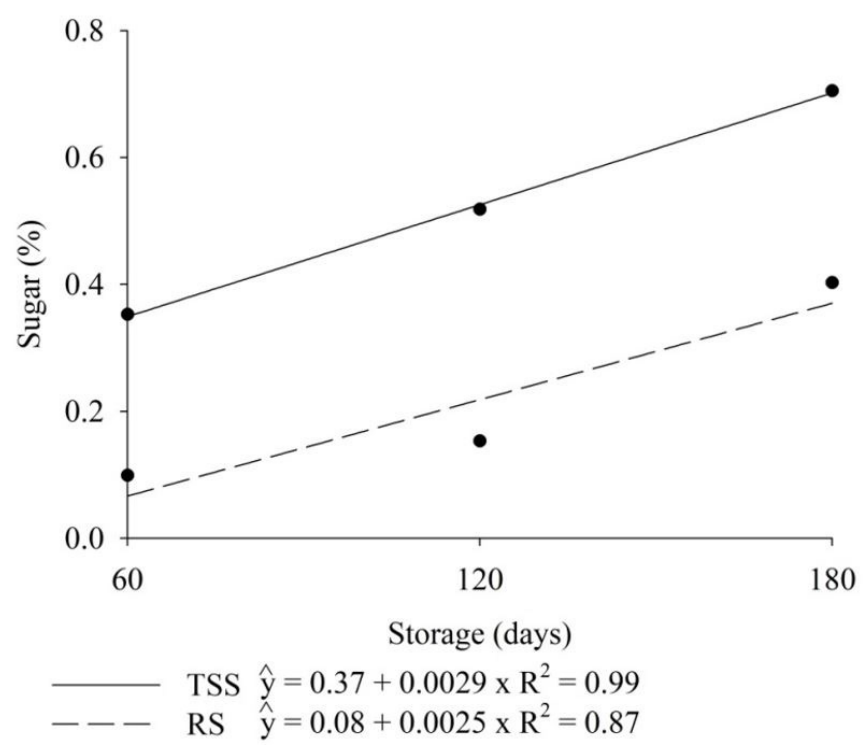

Figure 2. Total soluble sugars (TSS) and reducing sugars (RS) of potato tubers during storage for 180 days. 


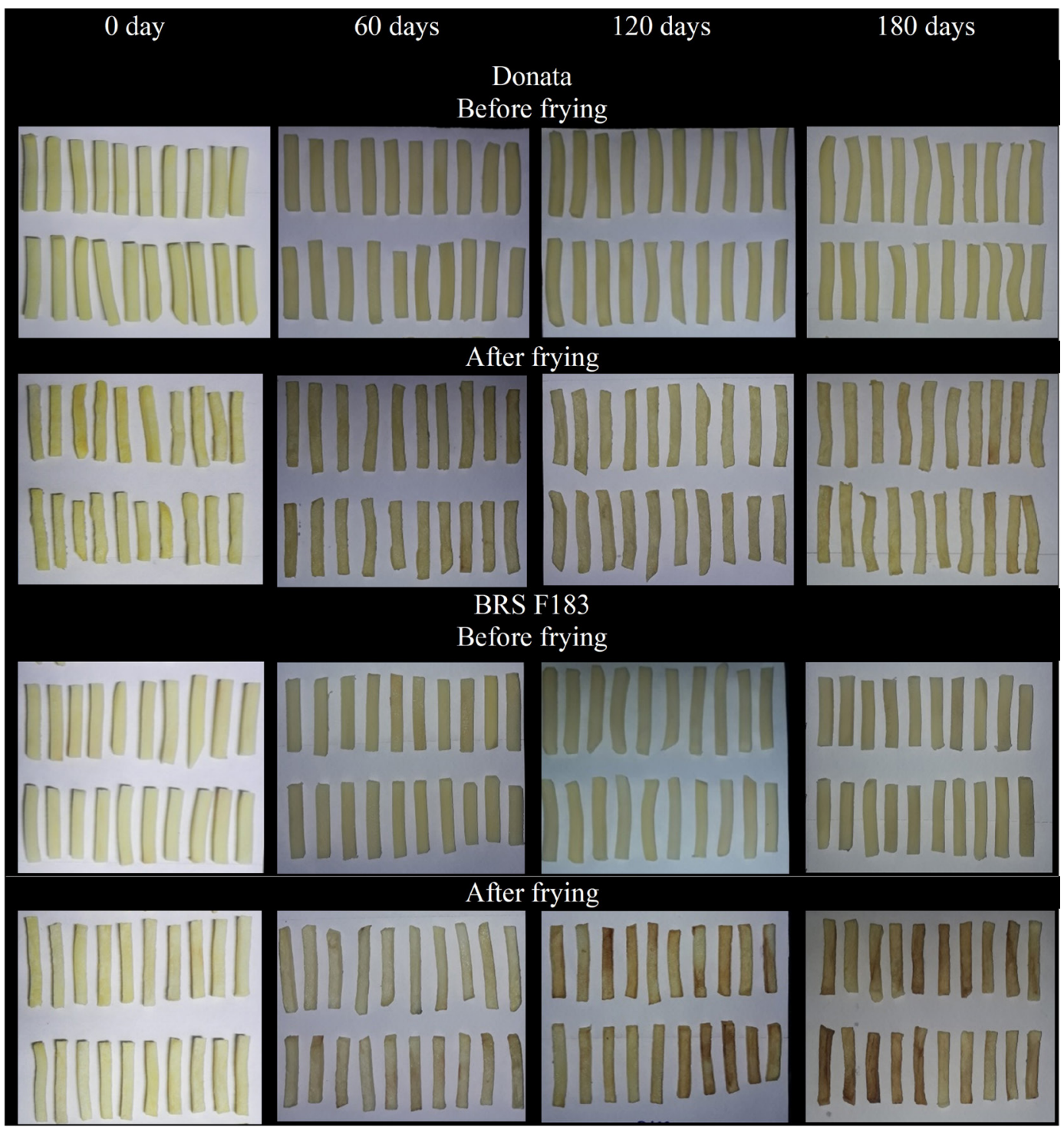

Figure 3. Coloring of potato sticks of Donata and BRS F 132 cultivars before and after frying for $180{ }^{\circ} \mathrm{C}$ for 4 min and storage at $8{ }^{\circ} \mathrm{C}$ for 0,60 , 120 and 180 days.

Delgado et al., 2016; Amjad et al., 2020), is indicative that the sticks would have an inadequate color for processing, however, this was not observed, and categories 2 and 3 are suitable for the potato processing industry.

This may occur, due to the non-enzymatic browning also being influenced by the content of amino acids, ascorbic acid and phenolic acids (Murniece et al., 2010).

Regardless of the cultivar and the storage time, the color of the sticks before frying was clear (Figure 3), without enzymatic browning due to the reaction of polyphenol oxidase (POD) with phenols (Paul et al., 2016). Studies by Santos et al. (2020) found an increase in the enzymatic activity of polyphenol oxidase with the storage time and reduction with the use of sprouting inhibitors, eugenol and menthol for up to 40 days. However, visually there was no enzymatic browning due to the increase in the storage time and growth of the sprouts. Indicating that the POD activity may have increased, but not sufficiently to cause browning. This assessment is important due to the pre-frozen sale of potato sticks in supermarket chains.

The parameter $\mathrm{L}^{*}$ decreased with the storage time in both cultivars, indicating the darkening of the sticks (Figure 4A). The values of $\mathrm{L}^{*}$ were lower in the cultivar BRS F132 compared to Donata and differed statistically in the points of 120 and 180 (Figure 4A), which corroborates with the observed with the classification of the coloring by the color scale.

The parameter $\mathrm{b}^{\star}$ also decreased with the storage time in both cultivars, however, there was no difference between cultivars (Figure 4B). The reduction in the yellow color of the sticks occurs due to the increase in browning, as observed in $L^{*}$.

Based on the color scale and $\mathrm{L}^{\star}$ and $\mathrm{b}^{\star}$ parameters, it is suggested that sticks with good coloring for industry meet $L^{*}$ above 55.8 and $\mathrm{b}^{\star}$ greater than 44.5 . 

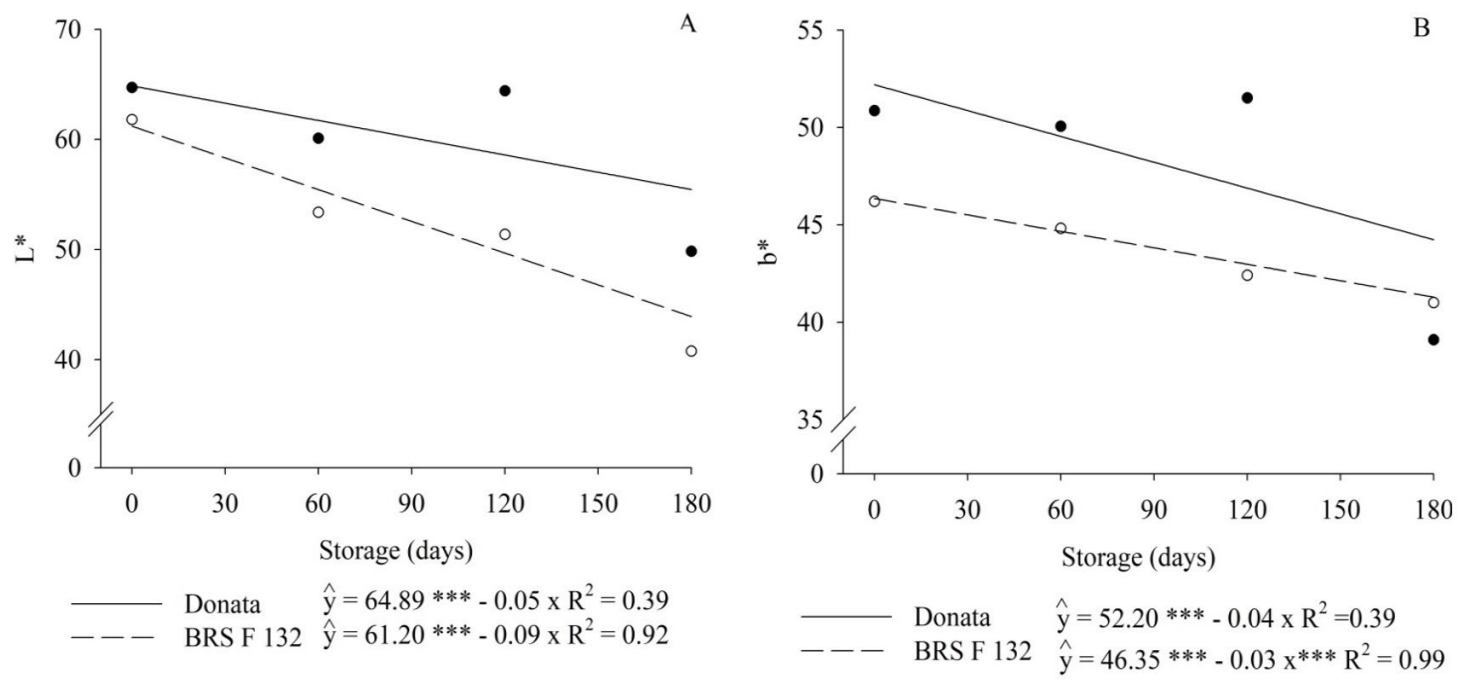

Figure 4. Parameters $L^{\star}(A)$ and $b^{\star}(B)$ of sticks of Donata and BRS F132 cultivars potato after frying for $180^{\circ} \mathrm{C}$ for 4 min and storage at $8{ }^{\circ} \mathrm{C}$ for $0,60,120$ and 180 days. $\left(L^{\star}-\mathrm{SMD}=6.35 ; \mathrm{b}^{\star}-\mathrm{SMD}=5.40\right)$.

\section{Conclusion}

Donata and BRS F132 cultivars are suitable for the potato processing industry, with 'Donata' showing better quality parameters. Conditioning at $8{ }^{\circ} \mathrm{C}$ is recommended in both cultivars that maintained the quality for 180 days.

\section{References}

Amjad, A., Javed, M. S., Hameed, A., Hussain, M., \& Ismail, A. (2020). Changes in sugar contents and invertase activity during low temperature storage of various chipping potato cultivars. Food Science and Technology (Campinas), 40(2), 340-345. http://dx.doi. org/10.1590/fst.00219.

Araújo, T. H., Pádua, J. G., Spoto, M. H. F., Ortiz, V. D. G., Margossian, P. L., Dias, C. T. S., \& Melo, P. C. T. (2016). Productivity and quality of potato cultivars for processing as shoestrings and chips. Horticultura Brasileira, 34(4), 554-560. http://dx.doi.org/10.1590/ s0102-053620160415.

Bastos, D. H. M., Shibao, J., Ferreira, E. L., \& Bombo, J. A. (2011). Produtos da reação de Maillard em alimentos industrializados. Nutrire, 36(3), 63-78.

Brião, V. B., Follmer, L., Souza, M., \& Rodrigues, V. M. (2011). Cinética do escurecimento não-enzimático com soluções modelo de açúcares e aminoácidos em pH neutro e ácido. Acta Scientiarum. Technology, 33(1), 87-93. http://dx.doi.org/10.4025/actascitechnol.v33i1.8360.

Cruz, C. D. (2006). Programa genes versão Windows. Aplicativo Computacional em Genética e Estatística (648 p.). Viçosa: UFV.

Di Stefano, V., \& Avellone, G. (2014). Food contaminants. Journal of Food Studies, 3(1), 88-103. http://dx.doi.org/10.5296/jfs.v3i1.6192.

Duarte-delgado, D., Nústez-López, C. E., Narváez-Cuenca, C. E., RestrepoSánchez, L. P., Melo, S., Sarmiento, F., Kushalappa, A. C., \& MosqueraVásquez, T. (2016). Natural variation of sucrose, glucose and fructose contents in Colombian genotypes of Solanum tuberosum Group Phureja at harvest. Journal of the Science of Food and Agriculture, 96(12), 42884294. http://dx.doi.org/10.1002/jsfa.7783. PMid:27133474.

Dubois, M., Gilles, K. A., Hamilton, J. K., Rebers, P. A., \& Smith, F. (1956). Colorimetric method for determination of sugars and related substances. Analytical Chemistry, 28(3), 350-356. http://dx.doi. org/10.1021/ac60111a017.

Elmore, S., Briddon, A., Dodson, A., Muttucumaru, N., Halford, N., \& Mottram, D. (2015). Acrylamide in potato crisps prepared from 20 UK-grown varieties: effects of variety and tuber storage time. Food Chemistry, 182, 1-8. http://dx.doi.org/10.1016/j.foodchem.2015.02.103. PMid:25842300.

Esposito, F., Nardone, A., Fasano, E., Triassi, M., \& Cirillo, T. (2017). Determination of acrylamide levels in potato crisps and other snacks and exposure risk assessment through a Margin of Exposure approach. Food and Chemical Toxicology, 108(Pt A), 249-256. http:// dx.doi.org/10.1016/j.fct.2017.08.006. PMid:28811114.

Faulkner, G. (2015). Essential trends inworld potatomarkets. Retrieved from https://www.prnewswire.com/news-releases/global-potato-market2019-2024---market-opportunities-and-future-trends-300875258.html.

Garcia, E. L., Carmo, E. L., Pádua, J. G., \& Leonel, M. (2015). Potencialidade de processamento industrial de cultivares de batatas. Ciência Rural, 45(10), 1742-1747. http://dx.doi.org/10.1590/0103-8478cr20140072.

Gonçalves, C., Rodriguez-Jasso, R. M., Gomes, N., Teixeira, J. A., \& Belo, I. (2010). Adaptation of dinitrosalicylic acid method to microtiter plates. Analytical Methods, 2(12), 2046-2048. http:// dx.doi.org/10.1039/c0ay00525h.

Halford, N. G., Curtis, T. Y., Muttucumaru, N., Postles, J., Elmore, J. S., \& Mottram, D. S. (2012). The acrylamide problem: a plant and agronomic science issue. Journal of Experimental Botany, 63(8), 2841-2851. http://dx.doi.org/10.1093/jxb/ers011. PMid:22345642.

Liu, Q., Li, J., Kong, B., Li, P., \& Xia, X. (2014). Physicochemical and antioxidant properties of Maillard reaction products formed by heating whey protein isolate and reducing sugars. International Journal of Dairy Technology, 67(2), 220-228. http://dx.doi.org/10.1111/14710307.12110.

McCombie, G., Biedermann, M., Biedermann-Brem, S., Suter, G., Eicher, A., \& Pfefferle, A. (2016). Acrylamide in a fried potato dish (rosti) from restaurants in Zurich, Switzerland. Food Additives \& Contaminants. Part B, Surveillance, 9(1), 21-26. http://dx.doi.org/ 10.1080/19393210.2015.1102974. PMid:26462849.

Minolta Corp. (1994). Precise color communication: color control from feeling to instrumentation (49 p.). Ramsey: Minolta Corporation Instrument Systems Division. 
Murniece, I, Karklina, D, Galoburda, R, \& Sabovics, M. (2010). Reducing sugar content and colour intensity of fried Latvian potato varieties. Raksti - Latv Lauksaimn Univ Latv, 24, 20-30.

National Agricultural Statistics Service - NASS, \& United States Department of Agriculture - USDA. (2013). Potatoes 2012 summary. Washington, D.C.: NASS/USDA.

Paul, V., Ezekiel, R., \& Pandey, R. (2016). Acrylamide in processed potato products: progress made and present status. Acta Physiologiae Plantarum, 38(12), 276. http://dx.doi.org/10.1007/ s11738-016-2290-8.

Pedreschi, F., Mariotti, M. S., \& Granby, K. (2014). Current issues in dietary acrylamide: formation, mitigation and risk assessment. Journal of the Science of Food and Agriculture, 94(1), 9-20. http:// dx.doi.org/10.1002/jsfa.6349. PMid:23939985.

Romani, S., Bacchiocca, M., Rocculi, P., \& Dalla Rosa, M. (2008). Effect of frying time on acrylamide content and quality aspects of French fries. European Food Research and Technology, 226(3), 555-560. http://dx.doi.org/10.1007/s00217-007-0570-7.

Santos, M. N. S., Lima, P. C. C., Araujo, F. F., Araújo, N. O., \& Finger, F. L. (2020). Activity of polyphenoloxidase and peroxidase in nondormant potato tubers treated with sprout suppressors. Food Science and Technology (Campinas), 40(Suppl 1), 222-227. http://dx.doi. org/10.1590/fst.08119.

United States Department of Agriculture - USDA. (1967). United states standards for grades of frozen french fried potatoes (p. 16). Washington: USDA.

Wiberley-Bradford, A. E., Busse, J. S., Jiang, J., \& Bethke, P. C. (2014). Sugar metabolism, chip color, invertase activity, and gene expression during long-term cold storage of potato (Solanum tuberosum) tubers from wild-type and vacuolar invertase silencing lines of Katahdin. BMC Research Notes, 7(1), 801. http://dx.doi.org/10.1186/17560500-7-801. PMid:25399251.

Wustman, R., Haverkort, A., Zhang, X., \& Rathee, G. (2011). An overview of the potato sector in India and prospects of Indo and Dutch cooperation (Project No. 3250214811. Applied Plant Research (Praktijkonderzoek Plant and Omgeving), part of Wageningen UR Business Unit Arable Farming, Multifunctional Agriculture and Field Production of Vegetables). Wageningen: Foundation Stichting Dienst Landbouwkundig Onderzoek. Retrieved from http://edepot. wur.nl/192686

Zorzella, C. A., Vendruscolo, J. L. S., Treptow, R. O., \& Almeida, T. L. (2003). Caracterização física, química e sensorial de genótipos de batata processados na forma chips. Brazilian Journal of Food Technology, 6, 15-24. 